WISSENSCHAFTSZENTRUM BERLIN FÜR SOZIALFORSCHUNG

SOCIAL SCIENCE RESEARCH CENTER BERLIN

\author{
Benny Geys \\ Looking across Borders: \\ A Test of Spatial Policy Interdependence using Local \\ Government Efficiency Ratings
}

SP II $2006-03$

February 2006

ISSN Nr. $0722-6748$

Research Area

Markets and Politics

Research Unit

Market Processes and Governance
Forschungsschwerpunkt Märkte und Politik

Abteilung

Marktprozesse und Steuerung 
Zitierweise/Citation:

Benny Geys, Looking across Borders: A Test of Spatial Policy Interdependence using Local Government

Efficiency Ratings, Discussion Paper SP II 2006 - 03, Wissenschaftszentrum Berlin, 2006.

Wissenschaftszentrum Berlin für Sozialforschung gGmbH,

Reichpietschufer 50, 10785 Berlin, Germany, Tel. (030) 25491 - 0

Internet: www.wz-berlin.de 


\section{ABSTRACT \\ Looking across Borders: A Test of Spatial Policy Interdependence using Local Government Efficiency Ratings}

by Benny Geys *

Spatial patterns in (local) government taxation and spending decisions have received a lot of scholarly attention recently. Still, the focus on taxation or expenditure levels in previous studies is incomplete. In fact, (rational) individuals are likely to consider the level of spending on (or taxation for) public goods provision simultaneously with how much public goods they actually receive thus assessing the 'price/quantity' of government policy (in relation to that of neighbouring jurisdictions) rather than concentrating on spending (or taxation) levels alone. Therefore, the present paper argues that incumbents may want their 'price/quantity' ratio to be close to that in neighbouring regions. Using Flemish local governments' efficiency ratings for the year 2000 (which relate tax revenues to the quantity of locally provided public goods), we confirm the existence of such neighbourhood effects in local government policies.

Keywords: Government efficiency, Flemish municipalities, local government, spatial interdependence

JEL Classification: D24, D60, H71, H72

* The author is grateful to Ashish Chaturvedi, Hilde Coffé, Bruno Heyndels, Dan Kovenock, Jan Vermeir and his colleagues at the WZB for insightful comments. 
Der Blick über die Grenze: Untersuchung von räumlichen Wechselbeziehungen in der Kommunalpolitik anhand von Effizienzbewertungen

In jüngster Zeit hat sich die Wissenschaft vermehrt für die räumlichen Muster der lokalen Besteuerung und Ausgabenentscheidungen interessiert. Dabei hat man sich in neueren Studien jedoch hauptsächlich auf die Betrachtung von Besteuerung und Ausgabenhöhe konzentriert. Diese Betrachtungsweise greift zu kurz, denn der (rationale) Bürger betrachtet die Höhe der öffentlichen Ausgaben (oder die Steuern dafür) und vergleicht, wie viel öffentliche Güter er eigentlich dafür bekommt. Er beurteilt also eher das Preis/Mengen-Verhältnis der Lokalpolitik im Vergleich zu den benachbarten Kommunen, als sich allein auf die Höhe der Ausgaben oder der Besteuerung zu konzentrieren. Es lässt sich zeigen, dass Amtsinhaber ein Preis/Mengenverhältnis anstreben, das dem der benachbarten Kommunen ähnlich ist. Die Auswertung von Daten aus dem Jahr 2000, die die Effizienz flämischer Lokalpolitik anhand des Verhältnisses von Steuereinnahmen zu lokal bereitgestellten öffentlichen Gütern bemessen, bestätigt die Existenz solcher Nachbarschaftseffekte in der Kommunalpolitik. 


\section{Introduction}

Since the seminal contributions of Salmon (1987) and Case et al. $(1989 ; 1993)$, spatial patterns in (local) governments' taxation and spending decisions have received a great deal of scholarly attention. Generally, empirical analyses indicate that governments do not take their taxation and expenditure decisions in isolation (for reviews, see Brueckner, 2003; Revelli, 2005). Various theoretical explanations of this interdependence have been brought forward. Some scholars refer to the beneficial or harmful externalities created by policies in one region on neighbouring regions (e.g. Kelejian and Robinson, 1993; Solé-Ollé, 2006). Others point to intergovernmental competition over a mobile tax base (e.g. Wilson, 1999; Buettner, 2001). A third group argues that policy "mimicking" can be rational for politicians when voters engage in relative performance assessment using the policies pursued by neighbouring governments as a yardstick. ${ }^{1}$ On the one hand, this can lead to a form of yardstick competition between neighbouring governments when voters use neighbours' performance to judge the competence of their own government (e.g. Salmon, 1987; Besley and Case, 1995). On the other hand, as argued by Ashworth and Heyndels (2000a), relative performance assessment might also affect voting behaviour (and thereby politicians' incentives to "mimic") because it generates so-called transaction (dis)utility to voters (Thaler, 1985) - which reflects the gain (loss) felt by voters in considering local policies to be better (worse) than the reference point.

While regarding various settings and time periods, one constant in previous empirical analyses of spatial interdependence is that they have concentrated on either taxation or expenditure levels. However, regarding taxation or spending levels in isolation disregards the fact that (rational) voters are likely to assess the costs of public goods provision relative to the level of public goods that is actually provided by the government. That is, they can be expected to regard the 'price/quantity' of public provisions (whether or not in relation to that of neighbouring governments) rather than make assessments based on the level of taxation or government spending alone. Solé Ollé (2003, 686, italics added), for example, claims that "in a decentralised system, a means of demonstrating to voters that a tax increase is necessary is to show that taxes are higher elsewhere for the same benefits provided". And Brueckner (2003, 178, italics added) argues that "a minimum level of public good provision relative to taxes (...) must be delivered for jurisdiction i's government to remain in office".

The present paper argues that the narrow focus on taxation or expenditure levels in previous work is not entirely satisfactory. Indeed, building on the notion that voters assess the 'price/quantity' of public provisions, we first illustrate that the ratio of tax revenues to public goods provision in a given jurisdiction is dependent upon that in neighbouring jurisdictions. We then empirically test this proposition using the relation between Flemish municipal governments' total tax revenues and their level of public goods provisions in the year 2000 as our main dependent variable. This dependent variable thus indicates how efficiently tax revenues are employed to generate public goods and can be interpreted as an indicator for the 'price/quantity' of local governments' policies. ${ }^{2}$ Our empirical results reveal the existence of a significant spatial pattern in local government efficiency ratings. Indeed, efficiency at one local government is associated with efficiency at its (geographical) neighbours. Interestingly, and in

1 In line with most previous empirical analyses of spatial policy interdependence, 'neighbourhood' is in the present paper interpreted as geographical proximity. Obviously, other interpretations are possible (e.g. in terms of similarity in socio-economic characteristics, government ideology or interarea population mobility) (e.g. Braicker, 2005).

2 To the best of our knowledge, the possibility of spatial interdependence in government efficiency ratings has not previously been explored. Such analyses have focused on a jurisdiction's own socioeconomic and political characteristics (for a review, see De Borger and Kerstens, 2000). 
contrast to some previous work, the presence of this spatial pattern is only weakly related to the political situation in the Flemish municipalities.

The remainder of the paper is structured as follows. The first section describes the theoretical framework. Our main extension to the existing theoretical work is that the ratio of tax revenues to public goods provision is central to interjurisdictional comparisons, rather than tax rates or expenditure levels as such. In the remaining sections, we empirically assess this proposition by testing for spatial patterns in the ratio of tax revenues to public goods provision across Flemish local governments. Specifically, section 2 provides information about the Flemish context. The measurement of the ratio of tax revenues to public goods provision (through local government efficiency ratings) is discussed in section 3. Section 4 presents the empirical analysis and section 5 concludes.

\section{Theoretical framework}

The literature examining spatial patterns in (local) governments' fiscal policies is rapidly expanding. Recent reviews of this literature by Brueckner (2003) and Revelli (2005) indicate that fiscal decisions in neighbouring jurisdictions tend to play a prominent role in the decision to set ones own tax rate or level of public goods provision. Several theoretical explanations have been suggested to explain this spatial interdependence: spillover effects, tax competition, yardstick competition and reference point effects. In section 1.1, we briefly consider the main traits of each of these models. Then, in section 1.2, we argue that the focus on either taxation or expenditure levels in previous theoretical and empirical studies may be unnecessarily restrictive. ${ }^{3}$ Instead, we suggest that the assessments of jurisdictions' (relative) performance is based on the ratio of tax revenues to public goods provision; thereby contending that this ratio will constitute an important competitive device between jurisdictions.

\subsection{Four models for fiscal interdependence}

As mentioned, four different theoretical models have been brought forward to explain the interdependence in policy outcomes across jurisdictions. The first of these, the spillover model, points at the beneficial or harmful externalities created by policies in one region on the well-being of inhabitants in neighbouring regions (e.g. Kelejian and Robinson, 1993; Solé-Ollé, 2006). Examples of such spillovers are numerous and include expenditures for recreational facilities, pollution prevention or public safety. Due to such spillover effects, the optimal policy in each jurisdiction depends on the policies chosen in neighbouring regions. Technically, the reaction function of any jurisdiction i - representing i's best response to choices in other jurisdictions - will have a non-zero slope (leading to a spatial pattern in the observed policies).

The second framework, the tax competition model, argues that governments often compete over a mobile tax base (e.g. Wilson, 1999; Buettner, 2001). This implies that they attempt to attract individuals (e.g. in case of income taxation) or firms (e.g. in case of profit taxation) through the taxation and spending decisions they make. It is assumed that policies in all jurisdictions jointly determine the distribution of this mobile tax base across jurisdictions. The reason is that when a firm or individual judges a certain region to be an optimal location for whatever reason (e.g. clean air, closeness to relatives or consumers, and so on), "there might

3 This argument appears harder to make for the spillover model. Hence, the remainder of this work will focus on the three remaining alternatives. Still, as this allows us to empirically distinguish between the theoretical explanations of spatial interactions, this need not be regarded as problematic. 
still be some degrees of freedom in choosing the specific community" (Buettner, 2001, 226). This leaves some leeway for local communities to engage in competition to attract the mobile tax base through its policy agenda. As a consequence, each jurisdiction is (indirectly) affected by the policies pursued in neighbouring jurisdictions. Once again, jurisdiction i's reaction function has a non-zero slope.

A third group of scholars has brought forward that one jurisdiction may mimic policy decisions in neighbouring jurisdictions as a rational response of politicians to voters who employ the policies pursued by neighbouring governments as a yardstick to assess their own government's competence (e.g. Salmon, 1987; Besley and Case, 1995). The idea is that politicians are forced into a "yardstick competition" with neighbouring jurisdictions (cfr. Shleifer, 1985) because voters use these jurisdictions to assess the quality of their own incumbents. 4

Finally, Ashworth and Heyndels (2000a) argue that the use of neighbouring governments' policies as a reference point generates so-called transaction (dis)utility to voters (cfr. Thaler, 1985). This transaction utility is the additional utility that people experience - besides the acquisition utility from a given policy in itself - from their consideration of this policy as good (or bad) relative to a reference point (in this case, neighbours' policies). As is well-known from prospect theory (e.g. Kahneman and Tversky, 1979), people tend to feel worse about a $25 \%$ income tax in the own jurisdiction when it is compared to a $20 \%$ income tax in neighbouring jurisdictions (for given levels of public goods) than when this tax is compared to a $30 \%$ income tax elsewhere. The reason is that they not only consider the $25 \%$ income tax as such, but also the $5 \%$ gain (or loss) compared to neighbouring jurisdictions. As this transaction utility is likely to also affect voting behaviour, the (rational) response of politicians is to follow each other's lead.

\subsection{Government efficiency as a competitive device}

In presentations (and empirical tests) of these explanations of spatial patterns in government policies, the discussion is usually restricted to either tax rates or the level of expenditures on certain public goods. While, as mentioned before, this is acceptable for the spillover model, it appears to be much less satisfactory for the remaining models. Indeed, competition between jurisdictions - whether this derives from the urge to attract a mobile tax base or because voters engage in relative performance assessments - is not likely to be restricted to either taxation or expenditure levels. In fact, Salmon $(1987,33 n)$, in the first application of relative performance evaluation to decentralised governments, already argued that "it is important (...) that voters take into account burdens of taxation as well as public services". Though this increases the information load placed on the voter, it is a quite essential point and similar concerns have been voiced in later papers. ${ }^{5}$ Alt and Lassen $(2006,2)$, for example, argue that "voters want more competent politicians in office, as they can provide more public goods for given levels of taxation and private consumption" (see also the citations of Solé Ollé, 2003 and Brueckner, 2003 in the introduction).

4 Interestingly, the 'assumption' that voters take policies in neighbouring jurisdictions into account and punish incumbents for relative underperformance finds considerable support in the literature assessing the political costs of taxation (e.g. Besley and Case, 1995; Bosch and Solé Ollé, 2004; Ågren, 2005; Vermeir and Heyndels, 2005; see, however, Revelli, 2002a).

5 Clearly, relative performance assessment relies on the individual's ability to analyse all the necessary information, such that this increased information load is not of trivial importance. We believe, however, that people generally have at least some impressions about the price/quantity of government provisions. 
Still, despite the recurrent expression of the need to regard what one pays (i.e. taxation or spending levels) and what one gets (i.e. the level of public goods provision), empirical analyses of spatial policy interdependence have continued to focus on taxation or spending levels in isolation. Note, however, that such a strict focus on, say, (relative) tax rates implicitly assumes that residents are more likely to accept higher tax rates in their own jurisdiction (or, at least, that the electoral retribution for these increases will be lower) when taxes have increased in neighbouring jurisdictions - even when the provision of public goods has increased in these neighbouring jurisdictions and remained constant in ones own jurisdiction. The reason is that voters concentrating exclusively on tax rate developments do not consider this unequal development in public goods provided. Intuitively, this makes little sense.

Let us turn to a more stylized formulation of the argument. ${ }^{6}$ Consider a situation where politicians only care about being re-elected. This preference might derive from a (possibly altruistic) desire to hold office and fend for the common good ('good' politicians) or from a craving to be in a position to extract as much rent as possible ('bad' politicians). The probability of being re-elected, however, depends on the incumbent's performance while in office. Evidently, the better one performs in the eyes of the electorate, the higher the chances of being re-elected. As voters are happier - and thus become more likely to re-elect their incumbent - when their utility level increases, politicians' preferences in any jurisdiction i $\left(U_{i}^{P}\right)$ can be given by:

$$
U_{i}^{P}=\mathrm{U}\left(U_{i}^{V}, \mathrm{p}_{\mathrm{i}}\right)
$$

where $U_{i}^{V}$ stands for the representative voter's utility level, $\mathrm{p}_{\mathrm{i}}$ indicates the utility politicians obtain from being in office (which can, but need not, derive from rent extraction) and superscripts $\mathrm{P}$ and $\mathrm{V}$ refer to the politician and the voter respectively. Assume further that voters want to maximise their utility and that this utility depends on private consumption $\left(\mathrm{c}_{\mathrm{i}}\right)$, the level of public goods provided by the government $\left(\mathrm{g}_{\mathrm{i}}\right)$ and a number of jurisdiction characteristics $\left(\mathrm{z}_{\mathrm{i}}\right)$; such that

$$
U_{i}^{V}=\mathrm{U}\left(\mathrm{c}_{\mathrm{i}}, \mathrm{g}_{\mathrm{i}}, \mathrm{z}_{\mathrm{i}}\right)
$$

Public goods are financed entirely through taxation, the cost of which is distributed equally over the jurisdiction's population. Therefore private consumption $\left(\mathrm{c}_{\mathrm{i}}\right)$ is determined by income $\left(\mathrm{y}_{\mathrm{i}}\right)$ minus the tax payment $\left(\mathrm{t}_{\mathrm{i}}\right)$ contributed towards the financing of public goods. The private budget constraint thus looks like: $c_{i}=y_{i}-t_{i}$. Maximization of (2) implies that voters prefer to obtain as much public goods as possible for a given tax payment (or, equivalently, pay as little taxes as possible for a given amount of public goods).

Public goods are provided by politicians who, as mentioned, can be either good or bad. Good politicians set the tax price of public goods equal to their cost while bad politicians try to extract as much rents as possible by setting the tax price of public goods above their costs. Crucially, however, voters cannot observe the minimal cost for providing public goods. This cost is stochastic and is only observed by the incumbent. Hence, while voters cannot gauge the maximum tax payment that should be associated with a given amount of public goods, politicians do. This asymmetric information problem presents the possibility for politicians to engage in rent-seeking behaviour. It can, however, be alleviated when voters take into account

6 For reasons of space, we only develop the argument for the yardstick competition framework though it is clear that a similar reasoning holds for the tax competition model and the reference points effects explanation. The exposition here builds on Besley and Case (1995) and Brueckner (2003). 
the behaviour of politicians in neighbouring jurisdictions. Indeed, when cost shocks in the provision of public goods are correlated across jurisdictions, the behaviour of other jurisdictions can provide valuable information about the quality of ones incumbent. ${ }^{7}$ In fact, when, all other things being equal, the level of taxes relative to public goods is higher in ones own jurisdiction compared to that in neighbouring jurisdictions - that is, when $t_{i} / g_{i}>t_{-i} / g_{-i}-$ the incumbent in the home jurisdiction is likely to be extracting rents (or might be extracting more rents than incumbents elsewhere). Therefore, they want to replace their incumbent at the next elections. For any given incumbent the probability of being re-elected $\left(\operatorname{Pr}_{\mathrm{i}}\right)$ thus not only depends on the ratio of tax revenues to public good provision in ones own jurisdiction $\left(t_{i} / g_{i}\right)$, but also on that same ratio in neighbouring jurisdictions $\left(t_{-i} / g_{-i}\right)$. That is:

$$
\operatorname{Pr}_{i}=f\left(t_{i} / g_{i}, t_{-i} / g_{-i}, z_{i}\right)
$$

where $z_{i}$ refers to a vector of characteristics of jurisdiction $i$ that help determine preferences. The incumbent in jurisdiction i chooses the ratio of tax revenues to public goods provision $\left(t_{i} / g_{i}\right)$ such as to maximize the probability of re-election. The first order condition of this problem can be (re)written as:

$$
t_{i} / g_{i}=R\left(t_{-i} / g_{-i}, z_{i}\right)
$$

where $\mathrm{R}$ represents a reaction function defining the optimal reaction of jurisdiction $\mathrm{i}$ (in terms of setting its ratio of tax revenues to public goods provision). It is clear that this depends on both $\left(t_{-i} / g_{-i}\right)$ and $z_{i}$ and, that is, on choices made in other jurisdictions and jurisdiction i's characteristics. In empirical applications, testing for a non-zero slope of this reaction function is effectively a test for the presence of spatial interdependence in the fiscal decisions of incumbents.

\section{Institutional setting}

The Flemish municipal setting offers a number of advantages to test the proposition outlined in section 1.2. Firstly, the institutional setting is the same in all municipalities. They all have the same parliamentary system and hold elections at the same point in time (i.e. the second Sunday of October) using the same electoral procedures. More specifically, local governments consist of the College of Mayor and Alderman (the executive body) and the local council (the legislative body). Councillors are chosen via municipal elections that take place once every six years and can be indefinitely re-elected (that is, there are no term limits). Following the election, the party (or coalition of parties) that controls a majority of the seats in the council decides on the composition of the executive board. The political system in the Flemish municipalities can thus be characterized as a parliamentary system where the executive board is formed by a political majority. Importantly, this homogeneous setting allows us to analyse spatial policy interdependence without needing to control for differing institutional factors.

7 The assumption of correlated cost shocks is crucial. Nothing can be learned from neighbouring government's reactions to different cost shocks. Still, certainly for smaller jurisdictions, cost shocks might well be correlated in reality. Importantly, however, it also assumes that politicians do not make agreements concerning the degree of rent extraction they pursue. Clearly, if all politicians agree to provide public goods at, say, twice their minimum cost, voters cannot learn the true level of wasted resources by regarding other jurisdictions. Though such collusion is clearly a theoretical possibility, it is doubtful whether it could also arise in reality. Uncertainty about the tolerance of rent-seeking behaviour across politicians may limit the occurrence of such political 'cartels'. 
Secondly, though the municipalities are the lowest level of government in Belgium (next to the national, regional and provincial levels), they have considerable autonomy in raising revenues and assume significant responsibilities at the expenditure side (e.g. in education, local infrastructure, public safety, social services and local public administration). In fact, Flemish local governments are allowed to pursue any policy that promotes their constituents' interests - and to determine how they finance these initiatives - provided these initiatives are not prohibited explicitly by federal legislation. This significant autonomy clearly shows from two elements in the revenue structure of the Flemish local governments. On the one hand, while surcharge taxes on the regional property tax (i.e. the local property tax, LPT) and the federal personal income tax (i.e. the local income tax, LIT) constitute a main revenue source of Flemish municipalities (about $83 \%$ of total tax income in 2000), significant variation exists in the extent to which the municipalities use these two revenue sources. Indeed, in the fiscal year 2000, the LIT rate varied between $0 \%$ and $8.5 \%$ of federal tax receipts while the minimum and maximum LPT rates were equal to $438 \%$ and $2000 \%$ of the regional tax respectively. This implies that inhabitants pay a supplement equal to approximately 5 to 20 times their regional government property tax bill (and 0-8.5 percent of their federal personal income tax bill) to the local government. Note that while the major part of income taxation thus accrues to the federal government rather than local governments, these local governments absorb the main part of property taxation in Flanders. Second, the average Flemish municipality collects about 15 different 'local' taxes, for which the tax base as well as the tax rate is determined by the local government (whereas they only set the tax rate for the surcharge taxes). Currently, more than 100 of such local taxes are in use and the list includes taxes on private swimming pools, on the distribution of telephone books, on transportation of drunken persons, on boats and so on.

Finally, the relatively small size of the Flemish municipalities (44 $\mathrm{km}^{2}$ on average) may constitute another beneficial element. Indeed, when the distance to ones reference group influences the ease of gathering information about the conditions in this reference group, the closeness of the neighbouring jurisdictions in the Flemish context entails that obtaining information about these neighbours is fairly easy. As such, the assessment of relative performance becomes feasible (thereby at the same time giving politicians an incentive to take neighbours' policies into account).

We should note here that these three elements have prompted several studies on spatial interdependence to use Flemish (and, by extension, Belgian) data. Heyndels and Vuchelen (1998), for example, show that a statistically significant spatial pattern exists in both LIT and LPT rates across Belgian municipalities. This suggests that incumbents take into account tax rates in neighbouring jurisdictions when setting their own rates. This is further corroborated by survey evidence in Flanders (Ashworth and Heyndels, 1997, 2000b). Specifically, local politicians' evaluation of how high (or low) local tax burdens are as well as their view on the need for tax increases (or decreases) is found to depend on the tax rates in neighbouring jurisdictions (see also Heyndels and Ashworth, 2003). Finally, Vermeir and Heyndels (2005, 12) show that voters in Flemish municipalities "use tax rates in neighbouring municipalities as a yardstick to evaluate tax policy in their own municipalities". This implies that politicians' mimicking behaviour may well be a rational reaction to the fact that voters assess local tax policies relative to that in neighbouring municipalities.

\section{Determining Flemish local government efficiency}

As mentioned in section 1, the present paper differs from previous research by focusing on the ratio of tax revenues to public goods provision as the indicator used for relative performance assessments (rather than concentrating on either tax rates or expenditure levels). In the 
empirical analysis (presented in section 4), this ratio is measured by relating the government's total tax revenues to its provision of public goods (and which we term local government efficiency). High efficiency signifies that the government needs only few (tax) resources to generate high levels of public goods while low efficiency indicates that high taxation levels are associated with low levels of public good provision. As such, it indicates how effective the incumbent government is in translating tax revenues into public goods - or, reversely, how strongly it indulges in rent-seeking behaviour. Hence, these efficiency ratings provide a way to operationalise the voter's actual cost-benefit assessment of the government's performance.

Several methods have been brought forward in the literature to measure efficiency (for an excellent introduction, see Lovell, 1993). In the present analysis, we employ a stochastic parametric reference technology. This implies that we determine the best practice frontier, which contains the input-output combinations designating optimal or efficient behaviour, on the basis of a specific functional form using econometric techniques. Moreover, contrary to deterministic approaches, the stochastic approach to efficiency measurement does not interpret any deviation from the best practice frontier as inefficiency, but rather differentiates between the effects of measurement error and inefficiency (Aigner et al., 1977 and Meeusen and van den Broeck, 1977). This allows us to limit the attribution of measurement error to inefficiency, which should therefore lead to a more accurate assessment of (in)efficiency. Technically, such stochastic frontier models have a composed error consisting of a symmetric component $(\mathrm{u})$ and a one-sided non-negative component (e) that represents inefficiency. While the former component is assumed to be white noise, the latter is assumed to be distributed half-normally (cfr. De Borger and Kerstens, 1996). Both error terms are assumed to be independent (Kuenzle, 2005). Employing a translogarithmic function (developed by Christensen et al., 1973) and assuming a multiplicative composite error term, the stochastic frontier model from which we derive our efficiency data can be written as (dropping municipality subscripts for convenience):

$$
\ln \mathrm{T}=\mathrm{a}+\sum_{j=1}^{n} \beta_{j} \ln y_{j}+1 / 2 \sum_{j=1}^{n} \sum_{k=1}^{n} \lambda_{j k} \ln y_{j} \ln y_{k}+\mathrm{u}+\mathrm{e}
$$

where $\mathrm{T}$ designates the input indicator, $y_{\mathrm{j}}$ indicates the output indicators, $n$ points to the number of outputs in the model and $\beta_{\mathrm{j}}$ and $\lambda_{\mathrm{jk}}$ are parameters to be estimated. ${ }^{8}$ Specifically, we rely on data from 305 of 308 Flemish municipal governments in the year 2000 to estimate local government efficiency ratings. ${ }^{9}$ Our input variable equals total tax revenues in the municipality. These revenues represent the (direct) cost to the voter from the public goods provided by the incumbent. ${ }^{10}$ To measure the level of local public goods provision, we include five output variables that have been employed in previous work on government efficiency in Flemish (and Belgian) municipalities (see Vanden Eeckaut et al., 1993; De Borger et al., 1994; De Borger and Kerstens, 1996). These include: (a) the number of subsistence grants beneficiaries, (b) the number of students in local primary schools, (c) the share of inhabitants older than 65,

8 Information on variation in input prices was not available (so that input prices are ignored). For the same reason it was not possible to control for differences in the quality of the output variables. However, since differences in the tax price to public goods ratio related to changes in the public good's quality should not instigate voter hostility, disregarding quality is likely to generate an underestimate of the sensitivity of jurisdictions to each other's policies (Besley and Case, 1995).

9 Data availability precluded the inclusion of the remaining 3 municipalities.

10 Note that more public goods could be provided at a given tax price when incumbents defer the costs of these expenditures to later periods by incurring debts - thereby artificially increasing their efficiency ratings. Importantly, however, as local governments in Belgium are only allowed to incur debts to finance large investment projects and not for current spending, deficit spending is unlikely to significantly affect our results. 
(d) the total population and (e) the surface of public recreational facilities (measured in hectare). These output variables relate to important responsibilities of local governments with respect to education and social and recreational services. Nevertheless, and as more extensively discussed in De Borger et al. (1994) and De Borger and Kerstens (1996), they are only crude proxies for the level of public goods provision. For example, the number of subsistence grants beneficiaries and total population are clearly not directly measuring local public good production, but rather serve as indicators for the services provided to low-income families and the various administrative tasks performed by the local government respectively. This, regrettably, reflects the general problem with defining and measuring public sector inputs and outputs (cfr. Levitt and Joyce, 1987; De Borger and Kerstens, 1996). ${ }^{11}$

We use the results from the cost frontier estimation of equation (5) to generate a measure for government efficiency using the procedure outlined in Jondrow et al. (1982). ${ }^{12}$ They particularly recommend to generate point estimates for the inefficiency element in the error component in equation (5) based on the mean of the conditional distribution (SF-Mean $=\mathrm{E}(\mathrm{u} \mid \mathrm{u}$ $+\mathrm{e})$ ). The efficiency measure resulting from this procedure will be used as our proxy for the ratio of tax revenues to public goods provision in the empirical analysis in the following section. 13

\section{Empirical analysis}

\subsection{Empirical Specification}

In this section we turn to the question whether our government efficiency rating (i.e. SF-Mean) demonstrates a spatial pattern across the Flemish municipalities. This would be expected if, as argued in section 1, these efficiency ratings (as an indicator for the 'price/quantity' of local governments' policies) are central to the competitive behaviour of rivalling jurisdictions. As a starting point, assume that the reaction function derived in section 1 (equation 4) can be characterized by the following spatial lag model:

$$
\text { SF-Mean }=\alpha+\rho W \text { SF-Mean }+\beta X+\varepsilon
$$

where $\alpha, \rho$ and $\beta$ are parameters to be estimated, $X$ represents a vector of control variables (further discussed below) and $\mathrm{W}$ is a square row-normalized spatial weights matrix indicating whether or not two municipalities are neighbours. Neighbours are thereby defined in a purely geographical sense as two municipalities that share a border. The entries in each row of this matrix are thus $1 / \mathrm{n}$ (with $\mathrm{n}$ the number of neighbours of the municipality in row $\mathrm{r}$ ) when the municipality in row $r$ shares a border with the municipality in column $\mathrm{c}$ and 0 otherwise. The

11 Panel data could admittedly be a help in resolving some of the problems related to these measurement issues (e.g. by allowing us to test the robustness of the empirical results). Unfortunately, time series data were not available for several of our output variables. Nor could we add the efficiency ratings generated by previous Belgian studies to our sample as these were derived either from all Belgian municipalities or from the Walloon municipalities only, while our data are restricted to the Flemish municipalities.

12 Note that the translogarithmic specification of the best practice frontier significantly outperforms the traditional Cobb-Douglas model. Indeed, the restriction that the coefficients for all quadratic terms and cross-products equals 0 can be strongly rejected $\left(\mathrm{Chi}^{2}(15)=26.75 ; \mathrm{p}<0.001\right)$.

13 We also estimated tax efficiency using a number of other well-known approaches: Free Disposal Hull, Data Envelopment Analysis assuming constant or variable returns to scale and a deterministic parametric frontier approach. The outcomes using the various approaches are highly correlated $(r>0.75)$ such that our results are unlikely to be affected by our choice of efficiency measurement. 
simple and intuitively appealing border-sharing criterion we employ is the most common approach in the literature. It can be justified by referring to the fact that proximity is likely to be a crucial element in the dissemination of information about local policies (Allers and Elhorst, 2005). Moreover, distance is significantly negatively linked to migration flows, indicating that "people prefer to move short distances if at all" (Day, 1992, 135). Hence, spatially contiguous neighbours may be the most important 'competitors'. Finally, we note that as local governments in Flanders publicly discuss their policies - that is, council meetings are open to the public (except when personnel issues are discussed) - the actual tax and spending decisions of neighbours are assumed to be observable. Therefore, we employ the contemporaneous ratio of tax revenues to public goods provision in the competing jurisdictions in the estimation of the model (see also Buettner, 2001; Revelli, 2001; 2002b; Bordignon et al., 2003; Allers and Elhorst, 2005).

Generally, a positive and significant coefficient estimate of $\rho$ can be interpreted as evidence of competition in local government efficiency ratings across the Flemish municipalities. Importantly, however, spatially correlated omitted variables or the existence of common shocks across municipalities may cause the estimate of $\rho$ to be spuriously significant. In that case, the true model would rather look like:

$$
\text { SF-Mean }=\alpha+\beta X+\varepsilon \quad \text { with } \varepsilon=\lambda W \varepsilon+v
$$

where $\mathrm{v}$ is an independently and identically distributed error term. Clearly, when spatial interdependence is driven only by such common shocks, no evidence in support of our main thesis is revealed. Another problem when estimating equation (6) is that OLS estimation leads to biased and inconsistent estimates due to the simultaneity in the determination of SF-Mean across jurisdictions (Cliff and Ord, 1973). Instead, one should use either instrumental variables analysis (IV) or maximum likelihood estimation (ML) (see Anselin, 1988). Though IVestimation has been argued to be somewhat less efficient than its ML counterpart (e.g. Das et al., 2003), it has the advantage of providing consistent results even in the presence of spatial error correlation (Kelejian and Prucha, 1998). It is thus important to take both these methodological issues into account when analysing spatial patterns in government efficiency across the Flemish municipalities. We more extensively return to these issues when discussing the empirical results in section 4.2.

Our set of control variables $(X)$ includes both socio-economic and political elements that may influence the municipality's efficiency rating (summary statistics for all variables are provided in table 1). All these variables are measured in 2000, except where noted otherwise. Firstly, we include income per capita in the municipality. Based on the argument that high-income citizens might be "more effective in demanding more efficient government" (Knack, 2002, 777), we expect a positive relation with government efficiency ratings. Secondly, we control for the share of owner-occupiers in the population. As homeownership entails a significant financial investment and local government policies are likely to influence housing prices (Oates, 1969; Reback, 2005), it is likely to encourage citizens to insist on efficient government behaviour (Green and White, 1997; DiPasquale and Glaeser, 1999). This leads us to expect a positive relation between homeownership and government efficiency ratings. ${ }^{14}$ Thirdly, we include population density - measured as the number of inhabitants per 100 square kilometres - to control for possible economies of scale in the supply of (local) public goods. The fourth and

14 Data availability leads us to use 1991 data on the percentage of houses with a known resident that are occupied by the owner. Note that this time-lag also mitigates the potential reverse causality problem that arises if citizens are more likely to buy (rather than rent) housing accommodation in efficiently run municipalities. We are grateful to Robert Nuscheler for this insight. 
final socio-economic control measures the number of pre-1977 communities that make up the present municipality. Following a large-scale municipal amalgamation operation in Belgium in 1976, most current 'municipalities' are composed of several pre-1977 'communities'. Crucially, inhabitants of the various pre-1977 communities may still identify with this initial community (for a similar identification argument, see Lago Penas, 2004; Geys, 2006). The ensuing 'intra-municipality' struggle may reduce overall efficiency of government performance - leading us to expect a negative relation between the number of per-1977 municipalities and local government efficiency.

We furthermore include two variables controlling for the financial situation of the municipality. On the one hand, the lagged level of long-term local public debt (measured as a share of total municipal revenues) gauges the strain of past (investment) decisions on municipal finances. While loans allow a municipality to spread its investment costs over the (economic) lifetime of the investment, interest and amortization of incurred debts must be paid out of the present budget. Hence, a given level of taxation then translates into lower levels of (non-durable) public goods provided in the current period (leading us to expect a negative relation between the lagged level of debt and government efficiency). On the other hand, grants awarded to the municipality by higher level governments allow it to supply more public goods for given tax income. Therefore, we expect a positive relation between efficiency and the level of grants (also measured as a share of total municipal revenues).

Finally, we introduce a set of political variables to control for a number of important characteristics of the local governments ruling in the year 2000 (and which were elected in 1994). The first of these political variables equals the effective number of parties in the governing coalition, measured as $1 / \sum_{i=1}^{n} p_{i}^{2}$, with $\mathrm{n}$ the number of coalition partners and $\mathrm{p}_{\mathrm{i}}$ the seat share of party $i$ in the College of Mayor and Aldermen (Laakso and Taagepera, 1979). We expect a negative relation with the local government's efficiency rating based on the argument that the level of government fragmentation increases the probability of government indecisiveness and gridlock (Alesina and Drazen, 1991; Tsebelis, 1995). ${ }^{15}$ As Tsebelis (1995) and Volkerink and de Haan (2001) argue that a similar gridlock effect could well arise when the coalition partners have varying ideological standpoints, we also include a measure for the ideological fragmentation of the governing coalition. This is measured as the standard deviation of the ideological positions of the coalition partners (Volkerink and de Haan, 2001). ${ }^{16}$ The third political control variable is the government's ideological position - defined as the weighed average ideological position of all government parties. ${ }^{17}$ This builds on the idea that right-wing politicians generally more fiercely support the workings of the market, while leftwing politicians favour higher government intervention (see Hibbs, 1977; Tavares, 2004). It is not a priori clear, however, how these different preferences would translate into higher (or lower) efficiency of the government itself.

15 To obtain a majority position in the local council, parties in Flemish municipalities often need to engage in coalition formation. Recent evidence indicates that the size of these coalitions significantly affects local government decision-making (e.g. Ashworth et al., 2005, 2006; Goeminne et al., 2005).

16 In mathematical terms, ideological fragmentation equals $\sum_{i=1}^{n}\left(p_{i}\left(\text { Complexion }_{i}-I C G\right)^{2}\right)$, where $p_{i}$ is the seat share of party $i$ in the College of Mayor and Aldermen, Complexion refers to the ideological position of this party on a Left-Right scale (from 0 to 10) and ICG amounts to the weighted average ideological position of all government parties (see below). The parties' placement on the ideological scale is based on a self-placement survey among presidents and spokesmen of the parties in the municipalities. The data derive from Deschouwer (1996) and range from 2.6 (Agalev) to 6.1 (VLD).

17 Using definitions for $n, \mathrm{p}_{\mathrm{i}}$ and Complexion as before (see previous footnote), government ideology is measured as $\sum_{i=1}^{n}\left(p_{i}\right.$. Complexion $\left._{i}\right)$. 
Table 1 about here

\subsection{Empirical results}

As previously mentioned, the analysis is based on data for the Flemish municipalities in the year 2000. Due to data availability with respect to some of our control variables, this analysis is based on 301 observations. The results are presented in table 2. Columns (1)-(3) estimate the model including all control variables, while in columns (4)-(6) insignificant variables are deleted one by one to generate a more efficient model.

Table 2 about here

Columns (1) and (4) present a non-spatial model estimated by OLS. However, the test statistic for Moran's I is in both cases statistically significant at beyond the $1 \%$ level, such that the null hypothesis of no spatial effects can be rejected. There thus appears to be a spatial pattern in the data. Unfortunately, Moran's I does not reveal whether a spatial lag model (in equation (6)) or a spatial error model (in equation (7)) is more appropriate. The most likely source of the spatial pattern is, however, provided by the robust LM tests developed by Anselin et al. (1996). These tests are robust in the sense that the presence of spatial lag (error) dependence does not bias the results for the test on spatial error (lag) dependence. The results - in the bottom row of table 2 - indicate that only the test for spatial lag dependence is statistically significant at conventional levels. Based on these findings, a ML spatial lag model appears most appropriate and the results of these estimations are given are reported columns (2) and (5). ${ }^{18}$ Still, given that the presence of spatial error dependence cannot be rejected, only IV estimation may provide consistent results (Kelejian and Prucha, 1998). These results are shown in columns (3) and (6), using neighbours' socio-economic covariates as instruments for neighbours' efficiency.

The coefficient of central interest in these estimations is the parameter testing for a spatial lag in the dependent variable $(\rho)$. In both specifications, this parameter is statistically significantly different from 0 , in line with the predictions from section 1 . The size of the coefficient indicates that a one percent higher efficiency rating in neighbouring municipalities is associated with an increase in ones own efficiency rating with $0.30-0.55$ percent. Hence, it appears that efficiency breeds efficiency. Municipalities with more efficient neighbours tend to be more efficient themselves. Importantly, to ensure that we are actually measuring spatial interdependence, we re-estimated the model using a weights matrix where neighbours are defined according to the alphabetical order of municipalities' names (cfr. Case et al., 1993; Ågren, 2005; Brown and Rork, 2005). Any given municipality thus is awarded one (or two) 'neighbours' preceding her in the alphabetical ordering and one (or two) 'neighbours' following her in this ordering. Since this alphabetical ordering of municipalities has nothing to do with the competitive forces between them, the use of such a weighing scheme should not lead to significant estimates of the spatial parameter $\rho$. Indeed, both when using one and two 'neighbours' on each side of a municipality in the alphabetical ordering, the estimations indicate the absence of spatial interactions. This substantiates our claim that the results in table 2 are effectively capturing inter-municipality competition.

18 Note that the log-likelihood of the ML spatial lag model exceeds that of a ML spatial error model, further indicating that the spatial lag model is the most suitable model. 
Referring back to the theoretical section, the spatial pattern established in table 2 could derive from competition over a mobile tax base or from politicians copying each others' policies in response to voters' relative performance assessments (i.e. yardstick competition and reference points effects models). To distinguish between these explanations, it has been argued that the political context should be taken into account (Besley and Case, 1995; Bordignon et al., 2003; Solé-Ollé, 2003; Ågren, 2005; Allers and Elhorst, 2005). Mimicking, so the argument goes, "should occur irrespective of re-election opportunities [if it] were due to tax competition" (Allers and Elhorst, 2005, 505), while the influence of political calculations on mimicking behaviour would provide support for the models that invoke electoral motives for politicians' mimicking behaviour. In other words, the crucial discriminating test rests on discovering discrepancies in politicians' behaviour under different political and electoral conditions. To investigate this in our setting, we test for differences in the size of the spatial interdependence parameter $(\rho)$ depending on the level of political fragmentation in the municipality, the proportion of parties in power and the size of the governing majority. ${ }^{19}$ The reasons for expecting these variables to influence incumbent's mimicking behaviour are as follows:

- The 'clarity of responsibility' hypothesis suggests that it is harder to assign blame to individual parties when the level of political fragmentation increases (Powell and Whitten, 1993). As acting on ones own desires is then politically less costly, fragmentation might reduce the extent of mimicking behaviour. On the other hand, coalition members are generally less certain about their position after the following elections. They not only need to win seats in the election, but also be successful in the ensuing coalition negotiations (Ashworth et al., 2006). This additional uncertainty may rather increase their incentive to mimic other's behaviour. To test these hypotheses, we follow Solé-Ollé (2003) and separate our sample in coalitions and one-party governments (and, as an alternative, in governments with more and less than two parties). ${ }^{20}$

- Parties' probability of regaining power after future elections may be higher when a larger share of the parties that gain representation in the local council are also taken up in the local government. The reason is that there are few alternative ways of forming a majority government. Hence, even when the local government performs badly, incumbents are more certain of re-election. We analyse whether in such a setting mimicking is less pervasive by splitting the sample in municipalities where the 'proportion of parties in power' is more (or less) than 0.5 (cfr. Allers and Elhorst, 2005).

- An alternative, and arguably somewhat more direct, indication of re-election odds is the size of the governing coalition. Since politicians can (generally) be more confident of reelection when they control a larger majority of the seats in the local council, we expect a lower need for mimicking behaviour under such circumstances (Bordignon et al., 2003; SoléOllé, 2003; Ågren, 2005; Allers and Elhorst, 2005). As a test for this hypothesis, we use the incumbent's control of more than 60 percent (or, alternatively, 65 and 70 percent) of the council seats as the dividing criterion between the municipal governments. ${ }^{21}$

The results are reported in table 3. To preserve space, and because the results are quantitatively similar as in table 2 , we suppress coefficient estimates for the control variables.

19 Technically, the spatial model is extended to allow for two regimes. We are grateful to Paul Elhorst for sharing his Matlab routines that allow us to perform this analysis.

20 Government fragmentation may, as argued in the literature on the Weak Government Hypothesis (e.g. Roubini and Sachs, 1989; Ashworth et al., 2005), also lead to legislative gridlock. This is likely to affect people's (or firm's) decisions about moving in or out of the municipality and thereby also have its importance for the extent of governments' mimicking behaviour in the tax competition model. Hence, the discriminating power of government fragmentation with respect to our three theories may only be weak. We are grateful to Bruno Heyndels for pointing this out to us.

21 Governments possessing higher seat shares are too few to allow for empirical testing. 
Table 3 about here

Table 3 shows that the political situation in the Flemish municipalities generally has only a minor effect on mimicking by incumbents. Indeed, in only two of the six estimations does the difference between the spatial parameter of the two groups approach statistical significance at conventional levels. Nonetheless, a number of observations tend to support the prediction that the probability of re-election affects incumbents' incentive to copycat politicians in other jurisdictions. Firstly, we find that the spatial parameter $\rho$ is higher for large coalitions - in which parties are generally less certain about returning to power - than for coalitions with less than two parties. This difference just fails to reach statistical significance at the ten percent level in the full model, but just surpasses this mark in the more efficient model (where insignificant variables are deleted one by one). Secondly, our results show that the spatial parameter $\rho$ is not statistically significantly different from 0 in municipalities where more than half of the parties in the local council are also part of the ruling government (i.e. PPP $>0.5$ ). In municipalities where less than half of the parties are in the governing coalition, there is a significant spatial pattern. Finally, turning to the effect of government's seat share in the local council, we observe that the difference in the spatial parameters are mostly in the expected direction and, interestingly, diverge with increasing majorities. The higher the governments' majority, the lower the spatial parameter $\rho$ becomes (and the larger the difference between the $\rho$ 's of both groups). Each of these three findings is in accordance with the idea that a higher probability of re-election is associated with lower apprehension with (and mimicking of) what happens in neighbouring jurisdictions. Nonetheless, though electoral motives appears to play some role in explaining the spatial pattern in the data, the (lack of) strength of the results would indicate that they are not the main reason for the observed policy interdependence.

Before turning to the conclusion, we make some brief remarks on the results of our control variables. The findings here are mostly supportive of our expectations, though they often fail to reach statistical significance. Significant support is found, however, for the hypothesis that a higher share of homeowners exerts a positive influence on government efficiency. This is in line with the idea that homeowners not only reside longer in an area, but also have an important financial stake there (cfr. Oates, 1969; Reback, 2005) - making it more important for them to actually demand efficient government behaviour. We also find that a higher number of pre-1977 communities in a municipality is negatively associated with efficiency. This could indicate that the inhabitants of merged municipalities still (at least partly) identify with their old community (cfr. Lago Penas, 2004; Geys, 2006) and that the resulting 'intra-municipality' competition reduces overall efficiency. Finally, and unsurprisingly, we find that higher grants are related to higher efficiency ratings (as less taxes are needed to finance a given level of public goods provision) while higher public debt is negatively related to government efficiency (as a larger part of tax revenues need to be used for interest and amortization payments).

\section{Conclusion}

Recent scholarship has recurrently shown that governments' (fiscal) policies often display a spatial pattern. High tax rates (spending levels) in one region tend to be associated with high tax rates (spending levels) in neighbouring regions and vice versa. While various theoretical explanations of this policy interdependence have been proposed, most of these build on relative performance assessment by a region's population (e.g. models of tax competition, yardstick competition and reference point effects). Still, the exclusive focus of such models on 
either taxation or expenditure levels - a regularity that is also encountered in previous empirical work - is in our view uncalled for. Indeed, (rational) individuals can be expected to take into account both the level of spending on (or taxation for) public goods provision and the level of public goods in assessing their government's policy agenda (whether or not they do so in relation to the policies of neighbouring governments).

Building on this notion that voters use the 'price/quantity' of public provisions as a basis for relative performance assessments, we illustrate that this leads to an interdependence between the ratio of tax revenues to public goods provision of a given jurisdiction and that of neighbouring jurisdictions. An empirical test using Flemish municipal efficiency ratings in the year 2000 (which relate total tax revenues to the level of public goods provisions) as an indicator for the 'price/quantity' of local governments' policies lends significant support for this proposition. Indeed, the analysis uncovers a significant spatial pattern in Flemish local government's efficiency ratings. The attempt to distinguish what theoretical model particularly drives this pattern indicates that the models invoking electoral motives for politicians' mimicking behaviour (i.e. yardstick competition and reference point effects) find only moderate support in our data. In contrast to previous findings, the presence of the spatial pattern is indeed only weakly related to the political situation in the Flemish municipalities. 


\section{References}

Ågren, H. (2005), Essays on Political Representation, Electoral Accountability and Strategic Interactions, Doctoral Dissertation, Uppsala: Uppsala University.

Aigner, D.J., C.A.K. Lovell and P. Schmidt (1977), Formulation and Estimation of Stochastic Frontier Production Function Models, Journal of Econometrics, 6: 21-37.

Alesina, A. and A. Drazen (1991), Why are Stabilizations delayed? American Economic Review, 81(5): 1170-1188.

Allers M.A. and J.P. Elhorst (2005), Tax Mimicking and Yardstick Competition among Local Governments in the Netherlands, International Tax and Public Finance, 12(4): 493-513.

Alt, J.E. and D.D. Lassen (2006), Fiscal Transparency, Political Parties and Debt in OECD Countries, European Economic Review, forthcoming.

Anselin, L. (1988), Spatial Econometrics: Method and Models, Dordrecht: Kluwer Academic Publishers.

Anselin, L., K. Bera, R. Florax and M. Yoon (1988), Simple Diagnostic Tests for Spatial Dependence, Regional Science and Urban Economics, 26: 77-104.

Ashworth, J. and B. Heyndels (1997), Politicians' Preferences on Local Tax Rates: An Empirical Investigation, European Journal of Political Economy, 13 (3): 479-502.

Ashworth, J. and B. Heyndels (2000a), Reference Point Effects in Local Taxation: it all depends on how you look at it, National Tax Journal, 53: 335-341.

Ashworth, J. and B. Heyndels (2000b), A Schema-Theoretic Approach to Politicians' Definitions on Tax Issues, Journal of Economic Psychology 21: 21-42.

Ashworth, J., B. Geys and B. Heyndels (2005), Government Weakness and Local Public Debt Development in Flemish Municipalities, International Tax and Public Finance, 12(4): 395-422.

Ashworth, J., B. Geys and B. Heyndels (2006), Determinants of Tax Innovation: The Case of Environmental Taxes in Flemish Municipalities. European Journal of Political Economy, forthcoming.

Besley, T. and A. Case (1995), Incumbent Behavior: Vote Seeking, Tax Setting and Yardstick Competition, American Economic Review, 85 (1): 25-45.

Bordignon, M., F. Cerniglia and F. Revelli (2003), In Search of Yardstick Competition: A Spatial Analysis of Italian Municipality Property Tax Setting, Journal of Urban Economics, 54: 199-217.

Bosch, N. and A. Solé-Ollé (2004), Yardstick Competition and the Political Costs of raising Taxes: An Empirical Analysis of Spanish Municipalities taking into account the Political Context, IEB Working Paper, n 2004/5, Institut d'Economia de Barcelona, Barcelona.

Braicker, K. (2005), The Spillover Effects of State Spending, Journal of Public Economics, 89: 529544.

Brueckner, J. (2003), Strategic Interaction among Governments: An Overview of Empirical Studies, International Regional Science Review, 26 (2): 175-188.

Brown, R.P. and J.C. Rork (2005), Copycat Gaming: A Spatial Analysis of State Lottery Structure, Regional Science and Urban Economics, 35: 795-807.

Buettner, T. (2001), Local Business Taxation and Competition for Capital: the Choice of the Tax Rate, Regional Science and Urban Economics, 31 (2-3): 215-245.

Case, A.C., J.R. Hines Jr. and H.S. Rosen (1989), Copycatting: Fiscal Policies of States and their Neighbors, NBER Working Paper No. 3032. 
Case, A.C., H.S. Rosen and J.R. Hines Jr. (1993), Budget Spillovers and Fiscal Policy Interdependence: Evidence from the States, Journal of Public Economics, 52 (3): 285-307.

Christensen, L.R., D.W. Jorgenson and L.J. Lawrence (1973), Transcendental Logarithmic Production Frontiers, Review of Economics and Statistics, 55 (1): 28-45.

Cliff A.D. and J.K. Ord (1973), Spatial Processes: Models and Applications, London: Pion.

Das, D., H.H. Kelejian and I.R. Prucha (2003), Finite Sample Properties of Estimators of Spatial Autoregressive Models with Autoregressive Disturbances, Papers in Regional Science, 82: 1-26.

Day, K.M. (1992), Interprovincial Migration and Local Public Goods, Canadian Journal of Economics, 25(1): 123-144.

De Borger, B., K. Kerstens, W. Moesen and J. Vanneste (1994), Explaining Differences in Productive Efficiency: An Application to Belgian Municipalities, Public Choice, 80: 339-358.

De Borger, B. and K. Kerstens (1996), Cost Efficiency of Belgian Local Governments: A Comparative Analysis of FDH, DEA and Econometric Approaches, Regional Science and Urban Economics, 26: 145-170.

De Borger, B. and K. Kerstens (2000), What is known about Municipal Efficiency? The Belgian Case and Beyond, in J. Blank (ed.), Public Provision and Performance: Contributions from Efficiency and Productivity Measurement, Amsterdam: Elsevier, pp. 299-330.

Deschouwer, K. (1996), Nationale partijen en gemeenteraadsverkiezingen, in J. Buelens and K. Deschouwer (Eds.), De dorpsstraat is de wetstraat niet, Brussels: VUBPress, pp. 13-25.

DiPasquale, D. and E.L. Glaeser (1999), Incentives and Social Capital: Are Homeowners better Citizens?, Journal of Urban Economics, 45: 354-384.

Geys, B. (2006), District Magnitude, Social Heterogeneity and Local Party System Fragmentation, Party Politics, 12 (2): 281-297.

Goeminne S., B. Geys and C. Smolders (2005), Political Fragmentation and Projected Tax Income: Evidence from Flemish Municipalities, mimeo.

Green, R.K. and M.J. White (1997), Measuring the Benefits of Homeowning: Effects on Children, Journal of Urban Economics, 41: 441-461.

Heyndels, B. and J. Ashworth (2003), Self-serving Bias in Tax Perceptions: Federalism as a Source of Instability, Kyklos, 56 (1): 47-68.

Heyndels, B. and J. Vuchelen (1998), Tax Mimicking in Belgian Municipalities, National Tax Journal, 60: 89-101.

Hibbs, D. (1977), Political Parties and Macro-economic Policy, American Political Science Review, 71: 1467-1487.

Jondrow, J., C.A.K. Lovell, I. Materov and P. Schmidt (1982), On the Estimation of Technical Inefficiency in the Stochastic Frontier Production Function Model, Journal of Econometrics, 19: 233-238.

Kahneman, D. and A. Tversky (1979), Prospect Theory: An Analysis of Decision under Risk, Econometrica, 47: 263-291.

Kelejian, H. and D. Robinson (1993), A Suggested Method of Estimation for Spatial Interdependent Models with Autocorrelated Errors and an Application to a Country Expenditure Model, Papers in Regional Science, 72 (3): 297-312. 
Kelejian, H. and I. Prucha (1998), A Generalised Spatial Two-Stage Least Squares Procedure for Estimating a Spatial Autoregressive Model with Autoregressive Disturbances, Journal of Real Estate Finance and Economics, 17: 99-121.

Knack, S. (2002), Social Capital and the Quality of Government: Evidence from the States, American Journal of Political Science, 46(4): 772-785.

Kuenzle, M. (2005), Cost Efficiency in Network Industries: Application of Stochastic Frontier Analysis, Unpublished doctoral dissertation, Zurich: Swiss Federal Institute of Technology.

Laakso, M. and R. Taagepera (1979), "Effective" Number of Parties: A Measure with Application to West Europe, Comparative Political Studies, 12(1): 3-27.

Lago Penas, I. (2004), Cleavages and Thresholds: the Political Consequences of Electoral Laws in the Spanish Autonomous Communities, 1980-2000, Electoral Studies, 23: 23-43.

Levitt, M. and M. Joyce (1987), The Growth and Efficiency of Public Spending, Cambridge: Cambridge University Press.

Lovell, C.A.K. (1993), Production Frontiers and Productive Efficiency, in H. Fried, C.A.K. Lovell and S. Schmidt (eds.), The Measurement of Productive Efficiency: Techniques and Applications, Oxford: Oxford University Press, pp. 3-67.

Meeusen, W. and J. van den Broeck (1977), Efficiency Estimation from Cobb-Douglas Production Functions with Composed Error, International Economic Review, 18 (2): 435-444.

Oates, W.E. (1969), The Effect of Property Taxes and Local Public Spending on Property Values: An Empirical Study of Tax capitalization and the Tiebout Hypothesis, Journal of Political Economy, 77(6): 957-971.

Powell, G.B.J. and G.D. Whitten (1993), A Cross-Section Analysis of Economic Voting: Taking Account of the Political Context, American Journal of Political Science, 37: 391-414.

Reback, R. (2005), Housing Prices and the Provision of Local Public Services: Capitalization under School Choice Programs, Journal of Urban Economics, 57: 275-301.

Revelli, F. (2001), Spatial Patterns in Local Taxation: Tax Mimicking or Error Mimicking?, Applied Economics, 33: 1101-1107.

Revelli, F. (2002a), Local Taxes, National Politics and Spatial Interactions in English District Election Results, European Journal of Political Economy, 18: 281-99.

Revelli, F. (2002b), Testing the Tax mimicking versus Expenditure Spillover Hypotheses using English Data, Applied Economics, 14: 1723-1731.

Revelli, F. (2005), On Spatial Public Finance Empirics, International Tax and Public Finance, 12 (4), 475-492.

Roubini N. and J.D. Sachs (1989), Political and Economic Determinants of Budget Deficits in the Industrial Democracies, European Economic Review, 33: 903-938.

Salmon, P. G. (1987), Decentralization as an Incentive Scheme, Oxford Review of Economic Policy, 3 (2): $24-43$.

Solé Ollé, A. (2003), Electoral Accountability and Tax Mimicking: The Effects of Electoral Margins, Coalition Government, and Ideology, European Journal of Political Economy, 29: 685713.

Solé Ollé, A. (2006), Expenditure Spillovers and Fiscal Interactions: Empirical Evidence from Local Governments in Spain, Journal of Urban Economics, forthcoming.

Tavares, J. (2004), Does Right or Left Matter? Cabinets, Credibility and Fiscal Adjustments, Journal of Public Economics, 88: 2447-2468. 
Thaler, R.H. (1985), Mental Accounting and Consumer Choice, Marketing Science, 4 (3): 199-214.

Tsebelis, G. (1995), Decision-making in Political Systems: Veto Players in Presidentialism, Parliamentarism, Multicameralism and Multipartyism, British Journal of Political Science, 25(3): 289-325.

Vanden Eeckhaut, P., H. Tulkens and M. Jamar (1993), Cost Efficiency in Belgian Municipalities, in H. Fried, C.A.K. Lovell and S. Schmidt (Eds.), The Measurement of Productive Efficiency: Techniques and Applications, Oxford: Oxford University Press, pp. 300-334

Vermeir, J. and B. Heyndels (2005), Tax Policy and Yardstick Voting in Flemish Municipal Elections, Applied Economics, forthcoming.

Volkerink, B. and J. de Haan (2001), Fragmented Government Effects on Fiscal Policy: New Evidence, Public Choice, 109(3-4): 221-242.

Wilson J. (1999), Theories of Tax Competition, National Tax Journal, 53: 269-304. 
Table 1: Summary statistics for control variables $(\mathrm{N}=301)$

\begin{tabular}{lcccc}
\hline Variable & Mean & St. Dev. & Min & Max \\
\hline SF-Mean & 81.914 & 10.504 & 31.532 & 96.619 \\
Income & 11.172 & 1.455 & 7.447 & 15.771 \\
Homeowners & 74.827 & 7.062 & 48.179 & 90.001 \\
Population concentration & 5.133 & 4.324 & 0.569 & 31.358 \\
Amalgamation & 2.980 & 2.069 & 1 & 12 \\
Lagged public debt & 1.278 & 0.522 & 0.270 & 4.340 \\
Grants & 12.772 & 3.289 & 6.788 & 39.201 \\
Government fragmentation & 1.777 & 0.744 & 1 & 5 \\
Ideological fragmentation & 0.569 & 0.811 & 0 & 2.890 \\
Ideological position & 5.007 & 0.592 & 2.7 & 6.1
\end{tabular}

Note: All variables are measured in 2000, except homeownership (where - due to availability data from 1991 where used) and the lagged level of public debt. 
Table 2: Estimation results

\begin{tabular}{|c|c|c|c|c|c|c|}
\hline Variable & $\begin{array}{c}\text { OLS } \\
\text { (1) }\end{array}$ & $\begin{array}{l}\mathrm{ML} \\
(2)\end{array}$ & $\begin{array}{l}\text { IV } \\
\text { (3) }\end{array}$ & $\begin{array}{c}\text { OLS } \\
\text { (4) }\end{array}$ & $\begin{array}{c}\mathrm{ML} \\
(5)\end{array}$ & $\begin{array}{l}\text { IV } \\
\text { (6) }\end{array}$ \\
\hline Intercept & $\begin{array}{c}23.909 \text { ** } \\
(2.09)\end{array}$ & $\begin{array}{l}5.694 \\
(0.62)\end{array}$ & $\begin{array}{l}-8.714 \\
(-0.63)\end{array}$ & $\begin{array}{c}29.620 \text { *** } \\
(4.42)\end{array}$ & $\begin{array}{c}13.063 \text { ** } \\
(2.03)\end{array}$ & $\begin{array}{l}0.774 \\
(0.07)\end{array}$ \\
\hline Income & $\begin{array}{l}-0.150 \\
(-0.32)\end{array}$ & $\begin{array}{l}-0.080 \\
(-0.20)\end{array}$ & $\begin{array}{l}-0.025 \\
(-0.06)\end{array}$ & - & - & - \\
\hline Homeowners & $\begin{array}{c}0.465^{* * *} \\
(5.54)\end{array}$ & $\begin{array}{c}0.392 * * * \\
(5.47)\end{array}$ & $\begin{array}{c}0.335 * * * \\
(4.54)\end{array}$ & $\begin{array}{c}0.445^{* * *} \\
(5.70)\end{array}$ & $\begin{array}{c}0.360 * * * \\
(5.73)\end{array}$ & $\begin{array}{c}0.297 * * * \\
(4.27)\end{array}$ \\
\hline $\begin{array}{l}\text { Population } \\
\text { concentration }\end{array}$ & $\begin{array}{l}0.081 \\
(0.53)\end{array}$ & $\begin{array}{l}0.136 \\
(0.93) \\
\end{array}$ & $\begin{array}{l}0.179 \\
(1.16) \\
\end{array}$ & - & - & - \\
\hline Amalgamation & $\begin{array}{l}-0.478^{*} \\
(-1.86)\end{array}$ & $\begin{array}{l}-0.402 \\
(-1.61)\end{array}$ & $\begin{array}{l}-0.341 \\
(-1.40)\end{array}$ & $\begin{array}{l}-0.476^{*} \\
(-1.92)\end{array}$ & $\begin{array}{l}-0.423 * \\
(-1.78)\end{array}$ & $\begin{array}{c}-0.384 \text { * } \\
(-1.65)\end{array}$ \\
\hline Lagged public debt & $\begin{array}{c}-2.936^{* * *} \\
(-2.67)\end{array}$ & $\begin{array}{c}-2.450 * * * \\
(-2.74)\end{array}$ & $\begin{array}{c}-2.065^{* *} \\
(-2.00)\end{array}$ & $\begin{array}{c}-2.864^{* * *} \\
(-2.70)\end{array}$ & $\begin{array}{c}-2.428 * * * \\
(-2.73)\end{array}$ & $\begin{array}{c}-2.104^{* *} \\
(-2.10)\end{array}$ \\
\hline Grants & $\begin{array}{c}1.837^{* * *} \\
(5.81)\end{array}$ & $\begin{array}{c}1.663 * * * \\
(9.73)\end{array}$ & $\begin{array}{c}1.526^{* * *} \\
(5.14)\end{array}$ & $\begin{array}{c}1.882 * * * \\
(6.62)\end{array}$ & $\begin{array}{c}1.698 * * * \\
(10.73)\end{array}$ & $\begin{array}{c}1.562 * * * \\
(5.67)\end{array}$ \\
\hline $\begin{array}{l}\text { Government } \\
\text { fragmentation }\end{array}$ & $\begin{array}{l}0.080 \\
(0.09)\end{array}$ & $\begin{array}{l}-0.007 \\
(-0.01)\end{array}$ & $\begin{array}{l}-0.076 \\
(-0.10)\end{array}$ & - & - & - \\
\hline $\begin{array}{l}\text { Ideological } \\
\text { fragmentation }\end{array}$ & $\begin{array}{l}0.863 \\
(0.87)\end{array}$ & $\begin{array}{l}0.706 \\
(0.82) \\
\end{array}$ & $\begin{array}{l}0.582 \\
(0.64)\end{array}$ & - & - & - \\
\hline Ideological position & $\begin{array}{l}1.092 \\
(0.87)\end{array}$ & $\begin{array}{l}0.942 \\
(0.91)\end{array}$ & $\begin{array}{l}0.824 \\
(0.74)\end{array}$ & - & - & - \\
\hline$\rho$ & - & $\begin{array}{c}0.305^{* * *} \\
(4.31) \\
\end{array}$ & $\begin{array}{c}0.545^{* * *} \\
(3.47) \\
\end{array}$ & - & $\begin{array}{c}0.299^{* * *} \\
(4.26) \\
\end{array}$ & $\begin{array}{c}0.522 * * * \\
(3.27) \\
\end{array}$ \\
\hline $\begin{array}{l}\mathrm{R}^{2} \\
\text { Loglikelihood } \\
\text { Moran I } \\
\text { LM spatial lag test } \\
\text { LM spatial error test } \\
\text { Hansen J }\end{array}$ & $\begin{array}{c}37.12 \\
2.857 * * * \\
13.194 * * * \\
2.829 *\end{array}$ & -1049.73 & 42.21 & $\begin{array}{c}36.76 \\
2.651 * * * \\
13.302 * * * \\
2.863 *\end{array}$ & -1050.74 & 41.78 \\
\hline
\end{tabular}

Note: $\mathrm{N}=301$; robust $t$-statistics in brackets; $\rho$ is the coefficient indicating a spatial lag in the dependent variable; ${ }^{* * *}$ denotes significance at $1 \%$ level, ${ }^{* *}$ at $5 \%$ and * at $10 \%$. Moran's I and (robust) LM tests are measures for spatial dependence in the residuals of the OLS regression. Hansen J tests for over-identification of the instruments used (and has a Chi distribution). 
Table 3: Spatial lag models for different regimes

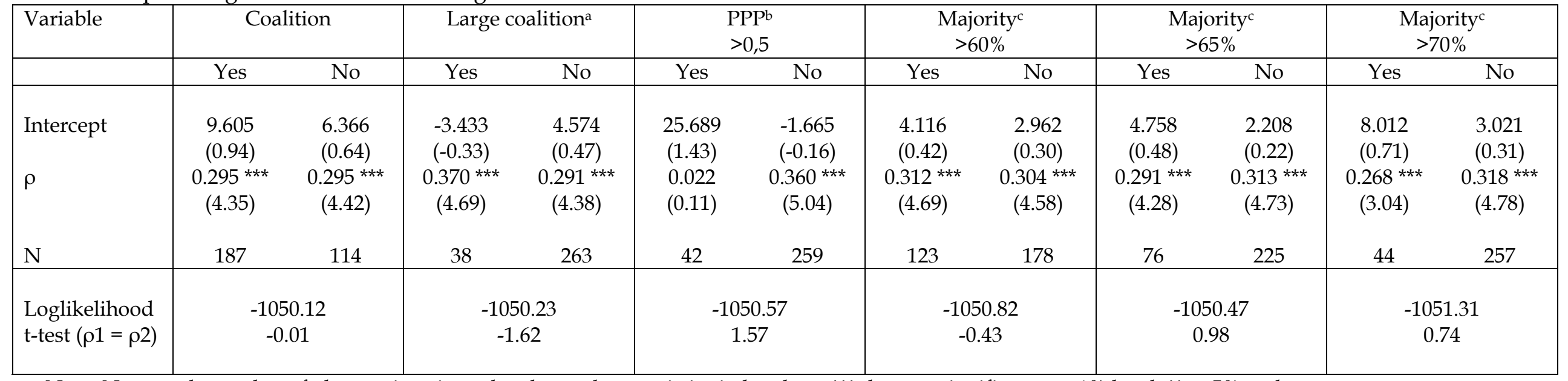

Note: $\mathrm{N}=$ equals number of observations in each subsample; $\mathrm{t}$-statistics in brackets; ${ }^{* *}$ denotes significance at $1 \%$ level, ${ }^{* *}$ at $5 \%$ and

* at $10 \%$; t-test $(\rho 1=\rho 2)$ attests the statistical significance of the difference of the spatial parameter in both subsamples.

a 'Large coalition' refers to coalitions with more than two parties

$\mathrm{b}$ 'PPP' indicates proportion of parties with representation in the local council that is part of the governing majority

c 'Majority' designates the seat share of the ruling government 